\title{
The global serological prevalence
} of Toxoplasma gondii in felids during the last five decades (1967-2017): a systematic review and meta-analysis

\author{
Mahbobeh Montazeri 1,2,3, Tahereh Mikaeili Galeh 1,2,3 ${ }^{1}$ Mahmood Moosazadeh4 , Shahabeddin Sarvi 1,2, \\ Samira Dodangeh ${ }^{1,2,3}$, Javad Javidnia ${ }^{3,5}$, Mehdi Sharif ${ }^{1,2}$ and Ahmad Daryani ${ }^{1,2^{*}}$
}

\begin{abstract}
Background: Felids (domestic and wild cats) are important in the epidemiology of the parasite Toxoplasma gondii because they are the only hosts that can excrete the environmentally resistant oocysts. We conducted a systematic review and meta-analysis to estimate the global prevalence of T. gondii in species of the family Felidae.

Methods: We searched seven databases (PubMed, Embase, Google Scholar, ScienceDirect, Scopus, Proquest and Web of Science) for studies reporting seroprevalence of T. gondii in felids from 1967 to 31 December 2017. A total of 217 published papers, containing 223 datasets were eligible for inclusion in the meta-analysis, comprised 59,517 domestic and 2733 wild cats from 1967 to 2017.

Results: The pooled global T. gondii seroprevalence was estimated to be 35\% (95\% Cl: 32-38\%) and 59\% (95\% Cl: 56-63\%) in domestic cats and wild felids, respectively, using random effects model. The seroprevalence was higher in Australia and Africa where the T. gondii seropositivity in domestic cats was 52\% (95\% Cl: 15-89\%) and 51\% (95\% Cl: 20-81\%), respectively. The lowest seroprevalence was estimated in Asia 27\% (95\% Cl: 24-30\%). The seroprevalence values for T. gondii in wild felids were 74\% (95\% Cl: 62-83\%) in Africa, 67\% (95\% Cl: 23-111\%) in Asia, 67\% (95\% Cl: 58-75\%) in Europe and 66\% (95\% Cl: 41-91\%) in South America.
\end{abstract}

Conclusions: Our study provides the global prevalence of $T$. gondii in species of the family Felidae and is a source of information to aid public health workers in developing prevention plans.

Keywords: Toxoplasma gondii, Serology, Domestic cat, Wild cat, Meta-analysis

\section{Background}

Toxoplasma gondii is a ubiquitous apicomplexan parasite responsible for a neglected parasitic disease, toxoplasmosis, in a wide variety of animals such as birds, livestock, and the great majority of homoeothermic vertebrates, including humans, worldwide acting as intermediate

*Correspondence: daryanii@yahoo.com

${ }^{1}$ Toxoplasmosis Research Center, Mazandaran University of Medical Sciences, Sari, Iran

Full list of author information is available at the end of the article hosts $[1,2]$. Based on formal reports, over one billion people in the world are estimated to be infected with T. gondii [3], which is transmitted mainly by ingestion of food, water, vegetables and fruits contaminated with sporulated oocysts shed from cats or ingesting tissue cysts from raw or undercooked meat [1]. Toxoplasma gondii prevalence in humans is different among different countries and in some regions can be high (e.g. Brazil, 77.5\%; Sao Tome and Principe, 75.2\%; Iran, 63.9\%; Colombia, 63.5\%; and Cuba, 61.8\%) [4]. 
The Centers for Disease Control and Prevention (CDC) reported that toxoplasmosis is the second most common cause of death due to food-borne diseases (an estimated 327 deaths) and the fourth leading cause of hospitalizations attributable to food-borne illness (an estimated 4428 hospitalizations) from the mid to late 2000 s in the USA [5].

The only definitive hosts of T. gondii, the members of the family Felidae (i.e. domestic cats and other felids), are the key animal species for the maintenance of this parasite [6]. This ubiquitous parasitic protozoan has three infectious forms: sporozoites (in oocysts), tachyzoites (rapidly multiplying form) and bradyzoites (tissue cyst form) [1]. The felids usually acquire T. gondii infection by orally ingesting meat containing viable T. gondii tissue cysts [7]. After ingestion, bradyzoites released from tissue cysts penetrate the epithelial cells of the intestinal tissues and initiate the formation of numerous asexual generations before the sexual cycle begins. Toxoplasma gondii completes its sexual lifecycle in the intestine of infected cats and millions of oocysts may be excreted into the environment between 3 and 18 days after infection, for several months resulting in the spread of toxoplasmosis to humans and animals $[8,9]$.

Toxoplasma gondii infection is important both in the veterinary and human medicine. It causes significant economic losses in terms of abortion in sheep and goats $[10,11]$. Infections in healthy humans are usually asymptomatic; however, it is considered to be an opportunistic and life-threatening parasite in immunocompromised individuals and newborns [8].

Considering the public health and economic importance of toxoplasmosis, in this study, we provide the first systematic review and meta-analysis to evaluate the global seroprevalence of $T$. gondii in the family Felidae.

\section{Methods}

The study was conducted according to the Preferred Reporting Items for Systematic Reviews and Meta-Analyses Protocols (PRISMA) for meta-analyses and systematic reviews of observational studies as described previously (Additional file 1: Table S1) [12].

\section{Search strategy}

In this systematic review and meta-analysis, we searched databases (PubMed, Embase, Google Scholar, ScienceDirect, Scopus, Proquest and Web of Science) for studies reporting seroprevalence of $T$. gondii in felines from 1967 to 31 December 2017. The searches were restricted to articles in English. The main MeSH terms used in electronic searches were: (Cat OR Felis) AND (Toxoplasma gondii OR toxoplasmosis) AND (Sero OR seroprevalence OR serology).

The citations were imported into EndNote X7.4 for management. After removing duplicate records; two reviewers (MM and SD) independently screened the title and abstract of each article and made the final article selection. A third reviewer (TM) was consulted in case of uncertainty or disagreement between the two reviewers. Reference lists of retrieved citations and published reviews were also searched for additional studies.

\section{Inclusion and exclusion criteria}

The cross-sectional studies were included if they investigated seroprevalence of T. gondii in felids providing original data and/or presented data that allowed us to assess the prevalence of $T$. gondii infection based on serological methods using serum identified up to 2017.

We excluded reviews, repeated studies, or human studies, as well as studies of animals which had been experimentally infected; non-serological investigations; studies with unclear testing methods, sample sizes of less than 25 felids [13], and lack of access to full article or insufficient data in the abstract.

\section{Data extraction and study quality assessment}

From each selected study, the following information was collected: continent, country, year of publication, the first author, the serological test used, the reported cut-off, period of sampling, sampling season, number of felids, number of seropositive felids, percent of positive felids (according the IgG results for male, female and total felids, respectively), type of felid and quality score of each study. The extracted data were collated into an Excel table and compared, any disagreements in the results were resolved by discussion, and the final data were checked by three of the authors (TM, MM and SD).

A quality assessment of included studies was performed as described previously [14]. The following items were examined and given a score based on a simple scale system (2 for "yes", 0 for "no", or 1 for "unsure"): (i) Was the research objective clearly described?; (ii) Was the sampling method defined in detail?; (iii) Was the period of study clearly stated? (iv) Was the serological test method clearly pointed out?; (v) Were the subjects categorized into different subgroups?

\section{Meta-analysis}

The seroprevalence of $T$. gondii and 95\% confidence intervals (CI) were estimated for each study by using STATA version 11 (STATA Corp., College Station, Texas). In all statistical analyses, the significance level was considered at $P<0.05$. 
In this study, we estimated the seroprevalence of $T$. gondii for continents by synthesizing the seroprevalence rates of all studies from each continent. The ratio of positive samples to total samples was defined as seroprevalence. The forest plot was used to presenting results of the meta-analysis in wild felids [15].

$I^{2}$ statistic was applied to assess the heterogeneity and inconsistency in the studies' results [16]. $I^{2}$ ranges between 0 and $100 \%$, and values of $\geq 50 \%$ were considered as indicators of high heterogeneity and inconsistency. Given that $I^{2}$ was substantial in this study; therefore, we used a random effects model at a 95\% CI, to give a more conservative estimate of the global $T$. gondii seroprevalence. Also, publication bias was employed amongst the selected studies, by applying the Egger's publication bias method [17]. Furthermore, to determine the source of heterogeneity, subgroup analyses were performed. In a subgroup analysis, we assessed the seroprevalence of $T$. gondii in males and females, and different geographical locations, South America, North America, Asia, Africa, Europe, Australia and Antarctica.

\section{Results}

\section{Study characteristics}

Of 9658 studies from the literature review from seven databases, 217 studies [203 studies on domestic cats (two studies containing 2 datasets) and 17 studies on wild felids (one study containing 2 datasets, three studies were common with studies in domestic cats)] had eligibility to be accounted in the systematic review and meta-analysis according to the inclusion criteria (Fig. 1).

A total of 59,517 domestic cats and 2733 wild felids were evaluated for T. gondii antibodies from 1967 to 31 December 2017 in different geographical locations worldwide. Our final sample for domestic cats included seven continents, Antarctica (1 study), Africa (10 studies), Asia (79 studies, containing 81 datasets), Australia (3 studies), Europe (45 studies), North America (31 studies) and South America (34 studies). The final sample for wild felids included five continents, Africa and Europe ( 1 study), Asia (3 studies containing 4 datasets), North America (6 studies) and South America (6 studies containing 5 datasets).

A map summarizing the seroprevalence of $T$. gondii in domestic cats and wild felids in different continents is shown in Fig. 2. The countries with the highest number of reports in domestic cats were Brazil (29 studies), China (17 studies), the USA (15 studies), Japan (13 studies) and Iran (11 studies) (Additional file 2: Table S2). Also, Brazil (5 studies) had the highest number of reports in wild felids (Table 1). Of the 217 studies, 99 and 5 studies included data for the sex of the domestic cats $(11,809$ male and 13,413 female) in 6 continents and of the wild felids (798 male and 680 female) in 2 continents.

The enzyme-linked immunosorbent assay (ELISA), the modified agglutination test (MAT) and the immunofluorescence assay test (IFAT) were the serological methods used in 56, 53 and 41 studies on domestic cats and in 1, 11 and 3 studies on wild felids, respectively. Given that very different serological methods were used in the studies (Table 1, Additional file 2: Table S2), we did not carry out subgroup analysis based on diagnostic methods.

The results of the literature search and characteristics of each study are provided in Table 1 and Additional file 2: Table S2. The list of countries with no data on $T$. gondii infection in domestic cats and wild felids according to inclusion criteria in this study is provided in Additional file 3: Table S3 and Additional file 4: Table S4, respectively.

\section{Meta-analysis results \\ Pooled global seroprevalence of T. gondii in felids}

The estimates of seroprevalence of $T$. gondii ranged between $0-97 \%$ and $15-100 \%$ in domestic cats and wild felids, respectively. The global pooled seroprevalence of T. gondii reported from 1967 to 2017 was 35\% (95\% CI: $32-38 \%$ ) and 59\% (95\% CI: 56-63\%) in domestic cats and wild felids, respectively (Table 2 and Fig. 3). Heterogeneity was substantial, $I^{2}=99.54 \%, P<0.001$ and $I^{2}=99.66 \%, P<0.001$ in domestic cats and wild felids, respectively.

\section{Pooled seroprevalence of $T$. gondii in felids in different continents}

The seroprevalence was higher in Australia and Africa where the T. gondii seropositivity in domestic cats was 52\% (95\% CI: $15-89 \%$ ) and 51\% (95\% CI: $20-81 \%$ ), respectively. The lowest seroprevalence estimated was in Asia (27\%, 95\% CI: 24-30\%) (Additional file 2: Table S2). Only one study was performed in Antarctica (Kerguelen Archipelago) and reported a seroprevalence of 51\% (95\% CI: $45-57 \%$ ) in 276 feral cats (Additional file 2: Table S2). Significant geographical differences were observed in pooled T. gondii seropositivity rates among domestic cats.

In wild felids, the highest pooled seroprevalence was observed in Africa (74\%, 95\% CI: 62-83\%), followed by Asia $(67 \%, 95 \%$ CI: $23-100 \%)$, Europe $(67 \%, 95 \% \mathrm{CI}$ : 58-75\%) and South America (66\%, 95\% CI: 41-91\%) (Fig. 3). 


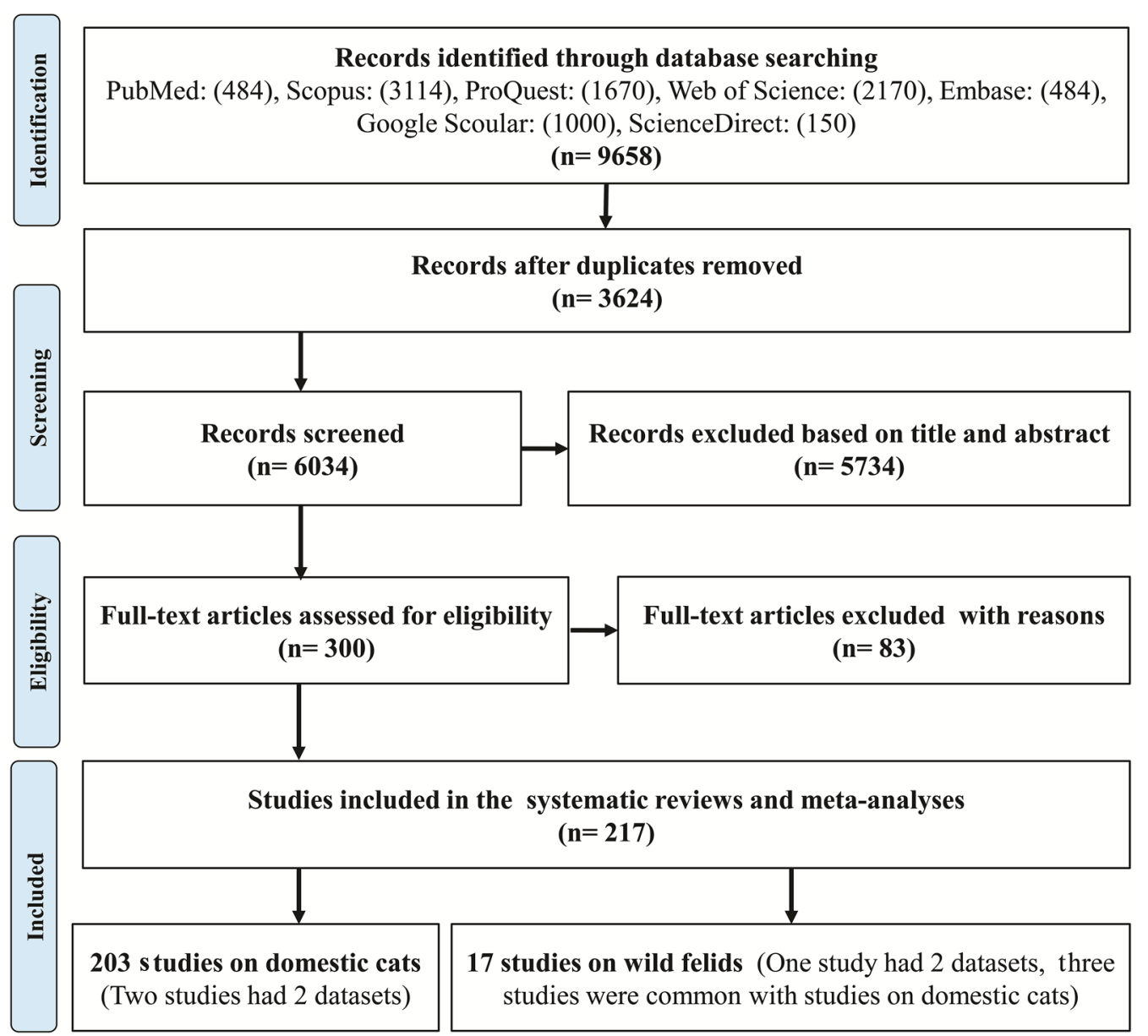

Fig. 1 PRISMA chart of the study design process

\section{Pooled seroprevalence of T. gondii in male and female felids in different continents}

In the subgroup analysis, the global pooled seroprevalence of toxoplasmosis was equal (33\%, 95\% CI: 29-37\%) in male and female domestic cats (Tables 3,4$)$. The highest pooled seroprevalence in male domestic cats was observed in Australia (62\%, 95\% CI: 54-70\%) followed by Europe (46\%, 95\% CI: 38-53\%) and Africa (43\%, 95\% CI: 12-75\%) (Table 3). Similarly, the highest pooled T. gondii seroprevalence in female domestic cats was observed in Australia (68\%, 95\% CI: 61-75\%) followed by Europe (47\%, 95\% CI: 38-56\%) and Africa (45\%, 95\% CI: 8-82\%) (Table 4). The estimates of the global seroprevalence of $T$. gondii in male and female wild felids were 61\% (95\% CI: 27-95\%) and 57\% (95\% CI: 19-96\%), respectively. A forest plot for seroprevalence of T. gondii in male and female wild felids in South and North America is provided in Fig. 4.

\section{Publication bias}

Egger's regression test revealed that publication bias exerted no significant influence on the overall prevalence of T. gondii infection in the cat population $(P=0.916)$.

\section{Discussion}

Only members of the family Felidae (domestic and wild cats) serve as definitive hosts for T. gondii worldwide [6]. In this report, we present the first meta-analysis estimating the prevalence of $T$. gondii infection in members of the family Felidae by continent, sex and globally from 1967 to 2017. According to previous reports, the worldwide seroprevalence of $T$. gondii in domestic cats was estimated to be $30-40 \%[10,18]$ and our finding was similar to this range. In the present study, the seroprevalence varied in different areas of the world and we found substantial differences in seroprevalence rates among the different continents. 


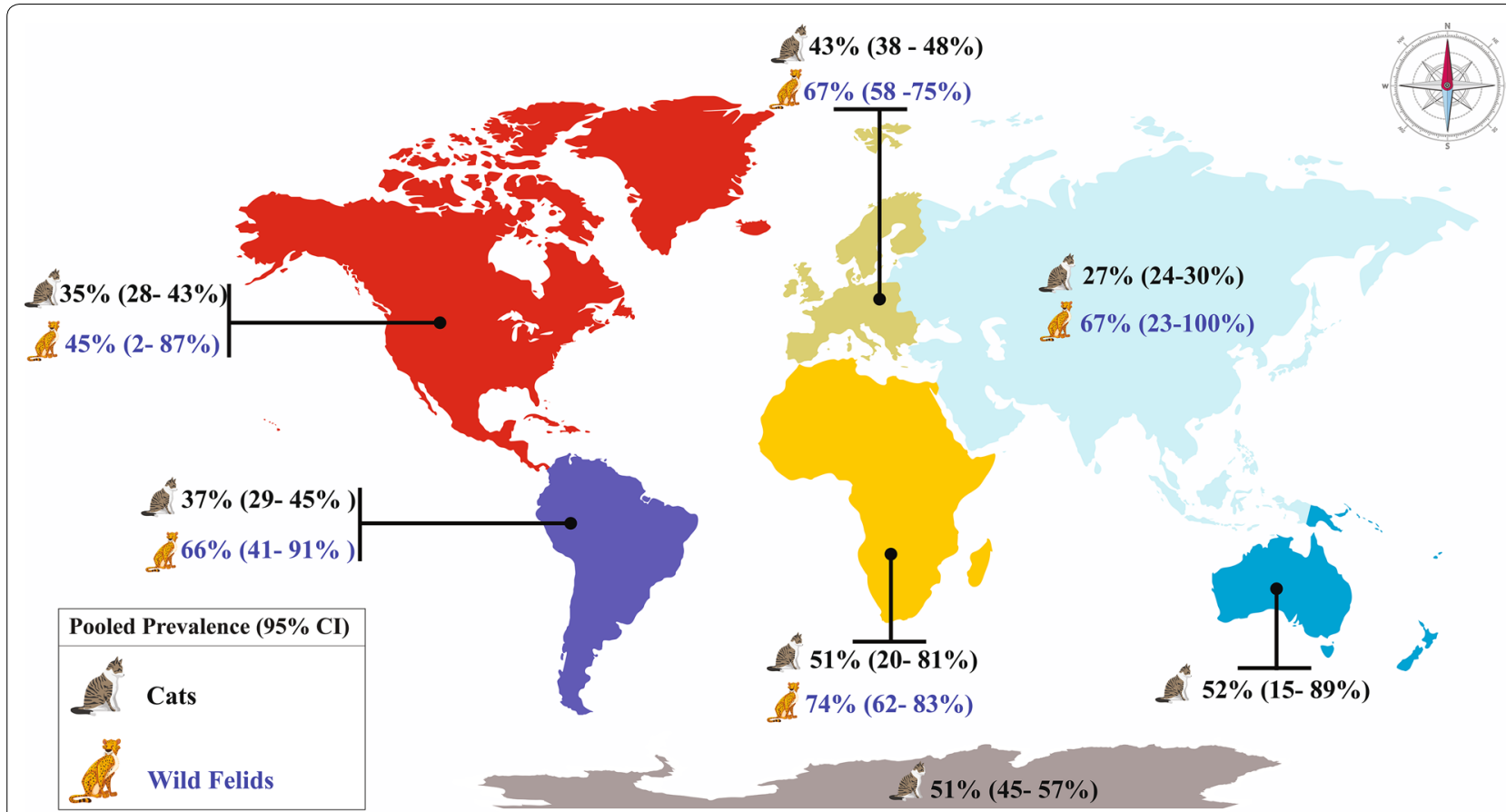

Fig. 2 Worldwide Toxoplasma gondii seroprevalence in domestic cats and wild felids from different continents. Data are reported as mean (range)

Accordingly, the T. gondii seroprevalence in domestic cats in different continents was in the following order: Australia $>$ Africa $>$ Antarctica $>$ Europe $>$ South America $>$ North America $>$ Asia; although it should be considered that the number of studies for Africa and Australia was relatively low (13 studies in total), and also only one study (276 animals) was included from Antarctica. The lowest seroprevalence was estimated in Asia (27\%; 79 studies, containing 81 datasets). Most studies were conducted within countries of Asia. The number of surveys was higher in Brazil (South America; 29 studies).

Overall, our study identified a number of key countries with or without data, emphasizing the need for further studies and more attention to T. gondii infection in cats in these countries. Additionally, the prevalence of toxoplasmosis in male and female domestic cats was higher in Australia, Europe and Africa. Moreover, the pooled seroprevalence of $T$. gondii infection in wild felids was higher in males (61\%) compared to females (57\%). However, Wilking et al. [19] reported that sex might be an important variable in humans; we do not believe it is a significant variable in cats, as under normal conditions, both male and female cats are at equal risk of exposure to T. gondii infection sources.

According to the CDC, T. gondii accounts for approximately $24 \%$ of all estimated deaths due to food-borne pathogens in the USA [20]. Toxoplasma gondii infection in food producing animals has become an important public health issue, as a source for human toxoplasmosis by transmission of the parasite via pork and wild boar meat and meat products [21,22]. Cats are the definitive host of T. gondii and an infected cat can be a major contributor to environmental contamination. Foroutan et al. [21] and Rostami et al. [22] reported that the presence of cats in the environment was significantly associated with a higher T. gondii seropositivity in pigs (19\%) and wild boars $(23 \%)$, respectively, worldwide.

So far, not many investigations have evaluated the prevalence of T. gondii in wild felids in the world. As shown in Table 1, the global pooled seroprevalence of $T$. gondii in wild felids was almost 59\% from 1967 to 2017 based on 17 studies from 12 countries. This prevalence varies according to different continents, from $45 \%$ in North America to $74 \%$ in Africa.

Toxoplasmosis is usually more prevalent, especially in moist, warm and low altitude regions [23]. This fact is associated with longer viability of $T$. gondii sporulated oocysts in a warm and humid areas [24]. It should be noted that these data are shown only for the regions which seroprevalence data is reported, as information in many other regions was scarce.

The strength of this investigation includes rigorous methodology, quality assessment, data extraction of included studies, the large sample size of the cats and wild felids included in the meta-analysis, and subgroup analyses considering continents and sex. There are two main limitations in the interpretation of this review. 
Table 1 Main features of studies regarding the global seroprevalence of Toxoplasma gondii in wild felids

\begin{tabular}{|c|c|c|c|c|c|c|c|c|c|}
\hline Country & Publication year & Method & Cut-off & $\begin{array}{l}\text { Period of } \\
\text { sampling }\end{array}$ & Sample size & Prevalence (\%) & $\begin{array}{l}\text { Wild felid } \\
\text { species }\end{array}$ & Quality score & References \\
\hline Southern Africa & 1999 & IFAT & $\geq 1: 50$ & 1984-1996 & 68 & 73.50 & $\begin{array}{l}\text { Non-domestic } \\
\text { captive and } \\
\text { free-ranging } \\
\text { felids }\end{array}$ & 8 & Cheadle et al. [25] \\
\hline Thailand & 2006 & LAT & $\geq 1: 64$ & $2002-2004$ & 136 & 15.40 & Captive felids & 8 & $\begin{array}{l}\text { Thiangtum et al. } \\
\text { [26] }\end{array}$ \\
\hline UAE & 2008 & MAT & $\geq 1: 25$ & $2001-2008$ & 36 & 86.11 & $\begin{array}{l}\text { Gordon's wild, } \\
\text { captive-born } \\
\text { and wild- } \\
\text { caught felids }\end{array}$ & 8 & Pas \& Dubey [27] \\
\hline Qatar & 2010 & MAT & $\geq 1: 25$ & 2009 & 27 & 77.78 & $\begin{array}{l}\text { Arabian sand } \\
\text { cat, African } \\
\text { wild cat, } \\
\text { cheetah, king } \\
\text { cheetah }\end{array}$ & 8 & Dubey et al. [28] \\
\hline UAE & 2010 & MAT & $\geq 1: 25$ & 2009 & 53 & 90.60 & $\begin{array}{l}\text { Gordon's wild } \\
\text { cat, Arabian } \\
\text { leopard, } \\
\text { cheetah, cara- } \\
\text { cal, African } \\
\text { caracal }\end{array}$ & 8 & Dubey et al. [28] \\
\hline France & 2013 & MAT & $\geq 1: 48$ & 1996-2006 & 112 & 67.00 & Wild cats & 10 & Afonso et al. [29] \\
\hline USA (Alaska) & 2001 & MAT & $\geq 1: 25$ & & 255 & 15.30 & Lynx & 8 & Zarnke et al. [30] \\
\hline Canada & 2001 & MAT & $\geq 1: 25$ & 1997-1998 & 116 & 44.00 & Lynx, bobcats & 10 & Labelle et al. [31] \\
\hline USA & 2003 & IFAT & $\geq 1: 50$ & & 101 & 44.55 & $\begin{array}{l}\text { Captive and } \\
\text { free-ranging } \\
\text { non-domestic } \\
\text { felids }\end{array}$ & 6 & Spencer et al. [32] \\
\hline $\begin{array}{l}\text { Midwestern } \\
\text { USA }\end{array}$ & 2008 & MAT & $\geq 1: 25$ & $2003-2005$ & 107 & 38.30 & $\begin{array}{l}\text { Cheetah, lynx, } \\
\text { clouded leop- } \\
\text { ard, African } \\
\text { lion, jaguar, } \\
\text { Amur leopard, } \\
\text { Persian } \\
\text { leopard, Amur } \\
\text { tiger, fishing } \\
\text { and Pallas's } \\
\text { cats, puma, } \\
\text { Texas puma, } \\
\text { snow leopard }\end{array}$ & 10 & $\begin{array}{l}\text { De Camps et al. } \\
\text { [33] }\end{array}$ \\
\hline $\begin{array}{l}\text { USA (Missis- } \\
\text { sippi) }\end{array}$ & 2017 & MAT & $\geq 1: 25$ & 2014 & 35 & 100 & Bobcats & 10 & Verma et al. [34] \\
\hline America & 2004 & LAT & $\geq 1: 64$ & 1984-1999 & 496 & 25.80 & $\begin{array}{l}\text { Pumas and } \\
\text { bobcats }\end{array}$ & 10 & Kikuchi et al. [35] \\
\hline Brazil & 2001 & MAT & $\geq 1: 20$ & $1996-2000$ & 37 & 64.90 & $\begin{array}{l}\text { European lynx, } \\
\text { jungle cat, } \\
\text { serval }\end{array}$ & 10 & Silva et al. [36] \\
\hline Brazil & 2001 & MAT & $\geq 1: 20$ & 1995-2001 & 865 & 54.60 & $\begin{array}{l}\text { Captive Neo- } \\
\text { tropical felids }\end{array}$ & 10 & Silva et al. [37] \\
\hline Brazil & 2010 & IFAT & $\geq 1: 40$ & & 161 & 63.40 & $\begin{array}{l}\text { Wild felids in } \\
\text { Brazilian zoos }\end{array}$ & 6 & Andre et al. [38] \\
\hline Brazil & 2010 & MAT & $\geq 1: 16$ & & 57 & 66.67 & $\begin{array}{l}\text { Neotropical } \\
\text { felids (leop- } \\
\text { ardus and } \\
\text { puma) }\end{array}$ & 8 & Ullmann et al. [39] \\
\hline Argentina & 2012 & ELISA & $\geq 1: 48$ & 2000-2008 & 40 & 47.50 & Geoffroy's cats & 9 & Uhart et al. [40] \\
\hline Brazil & 2015 & MAT & $\geq 1: 25$ & 2000-2009 & 31 & 100 & $\begin{array}{l}\text { Free-ranging } \\
\text { jaguars }\end{array}$ & 8 & Furtado et al. [41] \\
\hline
\end{tabular}


Table 2 Global and regional pooled seroprevalence of Toxoplasma gondii in domestic cats: results from studies performed in seven continents

\begin{tabular}{|c|c|c|c|c|c|c|c|}
\hline \multirow[t]{2}{*}{ Continent } & \multirow[t]{2}{*}{ No. of studies } & \multirow[t]{2}{*}{$n / N$} & \multirow{2}{*}{$\begin{array}{l}\text { Pooled prevalence } \\
(95 \% \text { CI) (\%) }\end{array}$} & \multirow[t]{2}{*}{ Weight } & \multicolumn{3}{|c|}{ Heterogeneity } \\
\hline & & & & & $\overline{d f}$ & $R^{2}(\%)$ & $P$-value \\
\hline Global & 204 & $16,722 / 59,517$ & 35 (32-38) & 100 & 203 & 99.54 & $P<0.001$ \\
\hline Antarctica & 1 & $141 / 276$ & $51(45-57)$ & 0.5 & 0 & - & - \\
\hline Africa & 10 & $583 / 1232$ & $51(20-81)$ & 4.94 & 9 & 99.79 & $P<0.001$ \\
\hline Asia & 79 & $4494 / 22,630$ & $27(24-30)$ & 39.75 & 80 & 98.39 & $P<0.001$ \\
\hline Australia & 3 & $288 / 443$ & $52(15-89)$ & 1.46 & 2 & - & - \\
\hline Europe & 45 & $4706 / 1116$ & $43(38-48)$ & 22.04 & 44 & 96.88 & $P<0.001$ \\
\hline North America & 31 & $4488 / 17,232$ & $35(28-43)$ & 14.64 & 22 & 98.61 & $P<0.001$ \\
\hline South America & 34 & $2022 / 6588$ & $37(29-45)$ & 16.67 & 33 & 99.32 & $P<0.001$ \\
\hline
\end{tabular}

Abbreviations:-, impossible to estimate, $d f$, degrees of freedom, $n$, number of positive samples, $N$, total number of samples

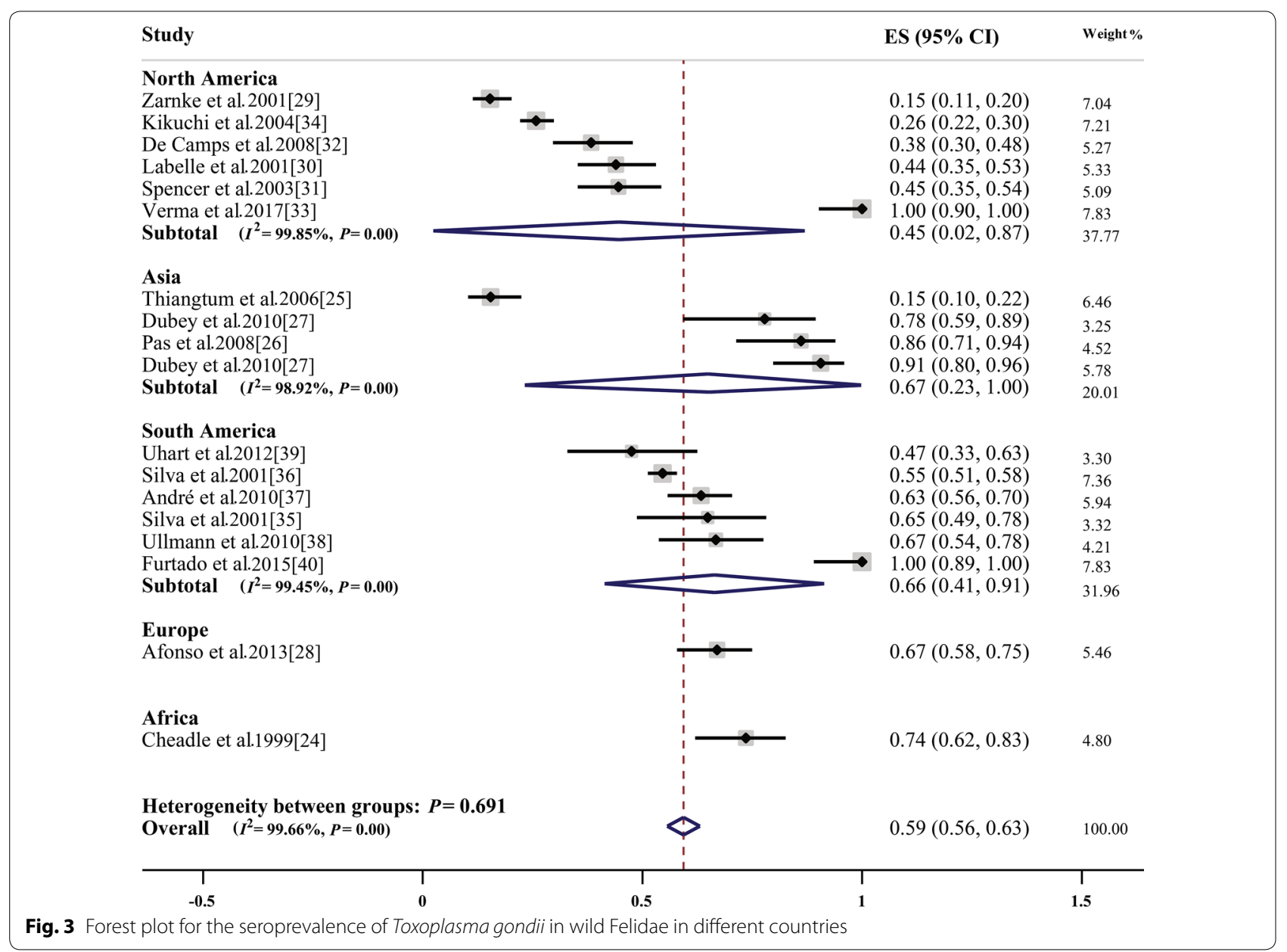

First, there was a lack of studies in some regions from many countries across the world, and many of the available studies suffered from limitations such as the lack of an adequate number of subjects, lack of balanced data on age (as an important item), and non-random sampling of the population at large. Secondly, a potential language bias might exist in our review, as the eligible studies were restricted to papers published in English. 
Table 3 Subgroup analysis for comparison of the prevalence of Toxoplasma gondii in male domestic cats globally and from different continents

\begin{tabular}{|c|c|c|c|c|c|c|c|}
\hline \multirow[t]{2}{*}{ Continent } & \multirow[t]{2}{*}{ No. of studies } & \multirow[t]{2}{*}{$n / N$} & \multirow{2}{*}{$\begin{array}{l}\text { Pooled prevalence } \\
(95 \% \mathrm{Cl})(\%)\end{array}$} & \multirow[t]{2}{*}{ Weight } & \multicolumn{3}{|c|}{ Heterogeneity } \\
\hline & & & & & $d f$ & $P^{2}(\%)$ & $P$-value \\
\hline Global & 101 & $3169 / 11,809$ & $33(29-37)$ & 100 & 100 & 98.72 & $P<0.001$ \\
\hline Africa & 7 & $184 / 445$ & $43(12-75)$ & 6.96 & 6 & 99.33 & $P<0.001$ \\
\hline Asia & 44 & $1164 / 6127$ & $28(23-33)$ & 43.64 & 43 & 97.54 & $P<0.001$ \\
\hline Australia & 2 & $71 / 118$ & $62(54-70)$ & 1.94 & 1 & - & - \\
\hline Europe & 18 & $1079 / 2453$ & $46(38-53)$ & 17.89 & 17 & 93.71 & $P<0.001$ \\
\hline North America & 10 & $301 / 940$ & $33(24-43)$ & 9.95 & 19 & 90.94 & $P<0.001$ \\
\hline South America & 20 & $370 / 1726$ & $25(18-32)$ & 19.63 & 9 & 96.85 & $P<0.001$ \\
\hline
\end{tabular}

Abbreviations: -, impossible to estimate, $d f$, degrees of freedom, $n$, number of positive samples, $\mathrm{N}$, total number of samples

Table 4 Subgroup analysis for comparison of the prevalence of Toxoplasma gondii in female domestic cats globally and from different continents

\begin{tabular}{|c|c|c|c|c|c|c|c|}
\hline \multirow[t]{2}{*}{ Continent } & \multirow[t]{2}{*}{ No. of studies } & \multirow[t]{2}{*}{$n / N$} & \multirow{2}{*}{$\begin{array}{l}\text { Pooled prevalence } \\
(95 \% \mathrm{CI})(\%)\end{array}$} & \multirow[t]{2}{*}{ Weight } & \multicolumn{3}{|c|}{ Heterogeneity } \\
\hline & & & & & $d f$ & $R^{2}(\%)$ & $P$-value \\
\hline Global & 101 & $3625 / 13,413$ & $33(29-37)$ & 100 & 100 & 99.00 & $P<0.001$ \\
\hline Africa & 7 & $204 / 489$ & $45(8-82)$ & 6.91 & 6 & 99.55 & $P<0.001$ \\
\hline Asia & 44 & $1211 / 6733$ & $27(22-32)$ & 43.32 & 43 & 97.56 & $P<0.001$ \\
\hline Australia & 2 & $86 / 135$ & $68(61-75)$ & 1.96 & 1 & - & - \\
\hline Europe & 18 & $1286 / 2849$ & $47(38-56)$ & 18.12 & 17 & 96.08 & $P<0.001$ \\
\hline North America & 10 & $335 / 1039$ & $32(24-40)$ & 9.90 & 19 & 87.51 & $P<0.001$ \\
\hline South America & 20 & $503 / 2168$ & $28(20-36)$ & 19.80 & 9 & 98.24 & $P<0.001$ \\
\hline
\end{tabular}

Abbreviations: -, impossible to estimate, $d f$, degrees of freedom, $\mathrm{n}$, number of positive samples, $\mathrm{N}$, total number of samples

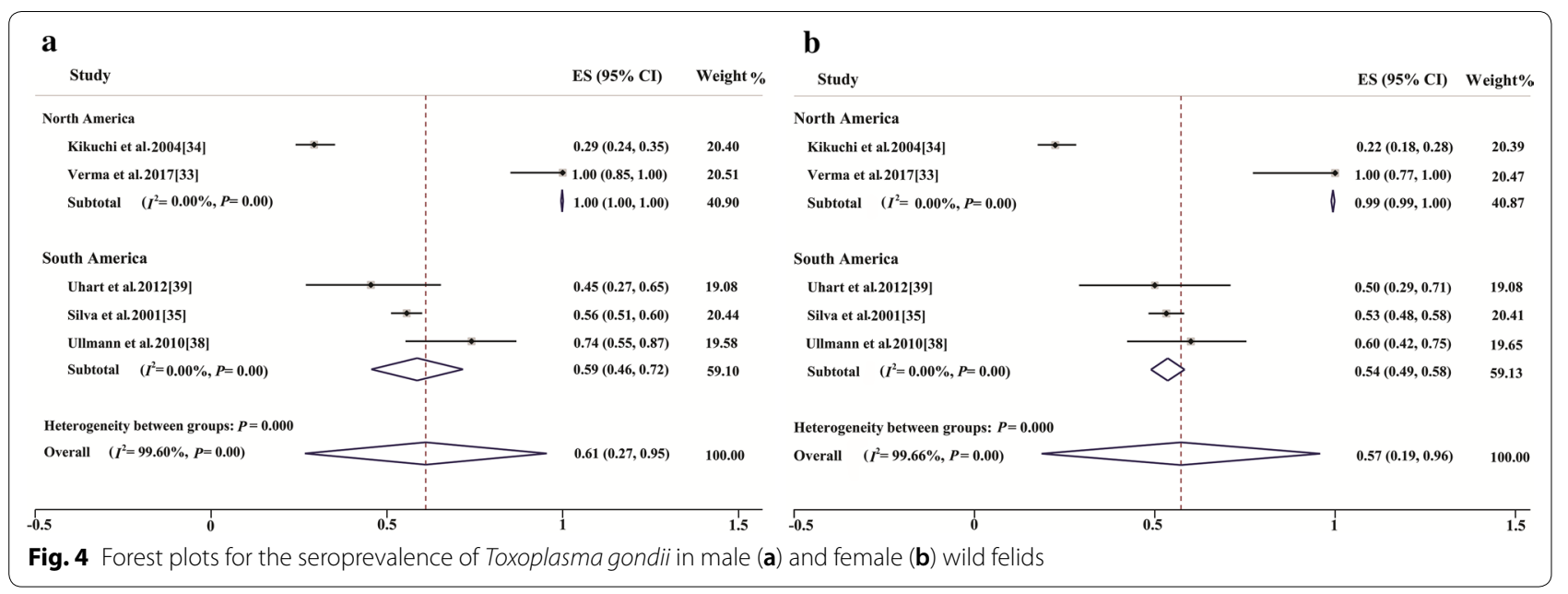

\section{Conclusions}

To the best of our knowledge, this is the first systematic review and meta-analysis providing a general view of the seroprevalence of $T$. gondii infection in members of the family Felidae (domestic and wild cats) from a global perspective. Health education, particularly toward avoiding contact with cats' feces and integrated preventive control programmes should also be considered. 


\section{Supplementary information}

Supplementary information accompanies this paper at https://doi. org/10.1186/s13071-020-3954-1.

Additional file 1: Table S1. PRISMA checklist.

Additional file 2: Table S2. Main features of studies regarding the global seroprevalence of Toxoplasma gondii in domestic cats.

Additional file 3: Table S3. List of countries without data on Toxoplasma gondii infection in domestic cats.

Additional file 4: Table S4. List of countries without data on Toxoplasma gondii infection in wild felids.

\section{Abbreviations}

CDC: Centers for Disease Control and Prevention; Cl: Confidence interval; IFAT: Immunofluorescence assay test; MAT: Modified agglutination test; PRISMA: Preferred reporting items for systematic reviews and meta-analyses.

\section{Acknowledgements}

We would like to thank the researchers of the Mazandaran University of Medical Sciences, Sari, Iran. Authors also would like to thank the Student Research Committee, Mazandaran University of Medical Sciences, Sari, Iran.

\section{Authors' contributions}

AD conceived the study. MM, SD, SS and TM initially searched the literature. TM and MM collected all data and assessed the included articles. MMO and MM analyzed and interpreted the data. JJ drew the graphic. MM drafted the manuscript. All authors read and approved the final manuscript.

\section{Funding}

Not applicable.

\section{Availability of data and materials}

Not applicable.

\section{Ethics approval and consent to participate}

Not applicable.

\section{Consent for publication}

Not applicable.

\section{Competing interests}

The authors declare that they have no competing interests.

\section{Author details}

${ }^{1}$ Toxoplasmosis Research Center, Mazandaran University of Medical Sciences, Sari, Iran. ${ }^{2}$ Department of Parasitology, Sari Medical School, Mazandaran University of Medical Sciences, Sari, Iran. ${ }^{3}$ Student Research Committee, Mazandaran University of Medical Sciences, Sari, Iran. ${ }^{4}$ Health Sciences Research Center, Addiction Institute, Mazandaran University of Medical Sciences, Sari, Iran. ${ }^{5}$ Department of Medical Mycology, School of Medicine, Mazandaran University of Medical Sciences, Sari, Iran.

Received: 19 July 2019 Accepted: 10 February 2020

Published online: 17 February 2020

\section{References}

1. Dubey JP. History of the discovery of the life cycle of Toxoplasma gondii. Int J Parasitol. 2009;39:877-82.

2. Hotez PJ. Neglected parasitic infections and poverty in the United States. PLoS Negl Trop Dis. 2014;8:e3012.

3. Hoffmann S, Batz MB, Morris JG Jr. Annual cost of illness and qualityadjusted life year losses in the United States due to 14 foodborne pathogens. J Food Prot. 2012;75:1292-302.

4. Pappas G, Roussos N, Falagas ME. Toxoplasmosis snapshots: global status of Toxoplasma gondii seroprevalence and implications for pregnancy and congenital toxoplasmosis. Int J Parasitol. 2009;39:1385-94.
5. Jones JL, Parise ME, Fiore AE. Neglected parasitic infections in the United States: toxoplasmosis. Am J Trop Med Hyg. 2014;90:794-9.

6. Elmore SA, Jones JL, Conrad PA, Patton S, Lindsay DS, Dubey JP. Toxoplasma gondii: epidemiology, feline clinical aspects, and prevention. Trends Parasitol. 2010;26:190-6.

7. Frenkel J, Dubey J, Miller NLJS. Toxoplasma gondii in cats: fecal stages identified as coccidian oocysts. Science. 1970;167:893-6.

8. Tenter AM, Heckeroth AR, Weiss LM. Toxoplasma gondii: from animals to humans. Int J Parasitol. 2000:30:1217-58.

9. Dubey JP, Frenkel JK. Cyst-Induced Toxoplasmosis in Cats. J Protozool. 1972;19:155-77.

10. Dubey JP, Beattie C. Toxoplasmosis of animals and man. 2nd ed. Boca Raton, Florida: CRC Press; 2010.

11. Hartley W, Marshall SC. Toxoplasmosis as a cause of ovine perinatal mortality. NZVJ. 1957;5:119-24.

12. Moher D, Shamseer L, Clarke M, Ghersi D, Liberati A, Petticrew M, et al. Preferred reporting items for systematic review and meta-analysis protocols (PRISMA-P) 2015 statement. Syst Rev. 2015;4:1.

13. Ambrosius WT. Topics in biostatistics, vol. 404. Totowa: Springer; 2007.

14. Ding H, Gao YM, Deng Y, Lamberton PH, Lu DB. A systematic review and meta-analysis of the seroprevalence of Toxoplasma gondii in cats in mainland China. Parasit Vectors. 2017;10:27.

15. Higgins JP, Thompson SG. Quantifying heterogeneity in a meta-analysis Stat Med. 2002;21:1539-58.

16. Higgins JP, Thompson SG, Deeks JJ, Altman DGJB. Measuring inconsistency in meta-analyses. BMJ. 2003;327:557-60.

17. Egger M, Smith GD, Schneider M, Minder CJB. Bias in meta-analysis detected by a simple, graphical test. BMJ. 1997;315:629-34.

18. Webster JP. Dubey, JP toxoplasmosis of animals and humans. Boca Raton, Florida: CRC Press; 2010.

19. Wilking $H$, Thamm M, Stark K, Aebischer T, Seeber F. Prevalence, incidence estimations, and risk factors of Toxoplasma gondii infection in Germany: a representative, cross-sectional, serological study. Sci Rep. 2016;6:22551.

20. Scallan E, Hoekstra RM, Angulo FJ, Tauxe RV, Widdowson MA, Roy SL, et al. Foodborne illness acquired in the United States - major pathogens. Emerg Infect Dis. 2011;1:7

21. Foroutan M, Fakhri Y, Riahi SM, Ebrahimpour S, Namroodi S, Taghipour A, et al. The global seroprevalence of Toxoplasma gondii in pigs: a systematic review and meta-analysis. Vet Parasitol. 2019;269:42-52.

22. Rostami A, Riahi SM, Fakhri Y, Saber $V$, Hanifehpour H, Valizadeh S, et al. The global seroprevalence of Toxoplasma gondii among wild boars: a systematic review and meta-analysis. Vet Parasitol. 2017;244:12-20.

23. Meerburg BG, Kijlstra A. Changing climate - changing pathogens: Toxoplasma gondii in north-western Europe. Parasitol Res. 2009;105:17-24.

24. Tutuncu M, Ayaz E, Yaman M, Akkan HA. The seroprevalance of Toxoplasma gondii in sheep, goats and cattle detected by indirect haemaglutinnation (IHA) test in the region of Van, Turkey. Vet J. 2003;80:401-3.

25. Cheadle MA, Spencer JA, Blagburn BL, Veterinarians wmopotAAoZ. Seroprevalences of Neospora caninum and Toxoplasma gondii in nondomestic felids from southern Africa. J Zoo Wildl Med. 1999;30:248-51.

26. Thiangtum K, Nimsuphun B, Pinyopanuwat N, Chimnoi W, Tunwattana W, Tongthainan D, et al. Seroprevalence of Toxoplasma gondii in captive felids in Thailand. Vet Parasitol. 2006:136:351-5.

27. Pas A, Dubey JP. Fatal toxoplasmosis in sand cats (Felis margarita). J Zoo Wildl Med. 2008:39:362-9.

28. Dubey JP, Pas A, Rajendran C, Kwok OC, Ferreira LR, Martins J, et al. Toxoplasmosis in sand cats (Felis margarita) and other animals in the Breeding Centre for Endangered Arabian Wildlife in the United Arab Emirates and AI Wabra Wildlife Preservation, the State of Qatar. Vet Parasitol. 2010:172:195-203.

29. Afonso E, Germain E, Poulle ML, Ruette S, Devillard S, Say L, et al. Environmental determinants of spatial and temporal variations in the transmission of Toxoplasma gondii in its definitive hosts. Int J Parasitol Parasites Wildl. 2013:2:278-85.

30. Zarnke RL, Dubey JP, Ver Hoef JM, McNay ME, Kwok OC. Serologic survey for Toxoplasma gondii in lynx from interior Alaska. J Wildl Dis. 2001;37:36-8.

31. Labelle P, Dubey J, Mikaelian I, Blanchette N, Lafond R, St-Onge S, et al. Seroprevalence of antibodies to Toxoplasma gondii in lynx (Lynx canadensis) and bobcats (Lynx rufus) from Quebec, Canada. J Parasitol. 2001:87:1194-6. 
32. Spencer JA, Higginbotham MJ, Blagburn BL. Seroprevalence of Neospora caninum and Toxoplasma gondii in captive and free-ranging nondomestic felids in the United States. J Zoo Wildl Med. 2003;34:246-9.

33. de Camps S, Dubey JP, Saville WJ. Seroepidemiology of Toxoplasma gondii in zoo animals in selected zoos in the midwestern United States. J Parasitol. 2008;94:648-53.

34. Verma SK, Cerqueira-Cezar CK, Murata FHA, Lovallo MJ, Rosenthal BM, Dubey JP. Bobcats (Lynx rufus) are natural definitive host of Besnoitia darlingi. Vet Parasitol. 2017:248:84-9.

35. Kikuchi Y, Chomel BB, Kasten RW, Martenson JS, Swift PK, O'Brien SJ. Seroprevalence of Toxoplasma gondii in American free-ranging or captive pumas (Felis concolor) and bobcats (Lynx rufus). Vet Parasitol. 2004;120:1-9.

36. Silva JCR, Ogassawara S, Marvulo MFV, Ferreira-Neto JS, Dubey JP. Toxoplasma gondii antibodies in exotic wild felids from Brazilian zoos. J Zoo Wildl Med. 2001;32:349-51.

37. Silva JC, Ogassawara S, Adania CH, Ferreira F, Gennari SM, Dubey JP, et al. Seroprevalence of Toxoplasma gondii in captive neotropical felids from Brazil. Vet Parasitol. 2001;102:217-24.
38. André M, Adania C, Teixeira R, Silva K, Jusi M, Machado S, et al. Antibodies to Toxoplasma gondii and Neospora caninum in captive Neotropical and exotic wild canids and felids. J Parasitol. 2010;96:1007-10.

39. Ullmann LS, da Silva RC, de Moraes W, Cubas ZS, dos Santos LC, Hoffmann $J \mathrm{~L}$, et al. Serological survey of Toxoplasma gondii in captive Neotropical felids from southern Brazil. Vet Parasitol. 2010;172:144-6.

40. Uhart MM, Virginia Rago M, Marull CA, Ferreyra HV, Pereira JA. Exposure to selected pathogens in Geoffroy's cats and domestic carnivores from central Argentina. J Wildl Dis. 2012;48:899-909.

41. Furtado MM, Gennari SM, Ikuta CY, De Almeida Jácomo AT, De Morais ZM, De Jesus Pena HF, et al. Serosurvey of Smooth Brucella, Leptospira spp. and Toxoplasma gondii in free-ranging jaguars (Panthera onca) and domestic animals from Brazil. PLoS ONE. 2015;10:e0143816.

\section{Publisher's Note}

Springer Nature remains neutral with regard to jurisdictional claims in published maps and institutional affiliations.
Ready to submit your research? Choose BMC and benefit from:

- fast, convenient online submission

- thorough peer review by experienced researchers in your field

- rapid publication on acceptance

- support for research data, including large and complex data types

- gold Open Access which fosters wider collaboration and increased citations

- maximum visibility for your research: over $100 \mathrm{M}$ website views per year

At $\mathrm{BMC}$, research is always in progress.

Learn more biomedcentral.com/submissions 